\title{
DKC1 wt Allele
}

National Cancer Institute

\section{Source}

National Cancer Institute. DKC1 wt Allele. NCI Thesaurus. Code C113620.

Human DKC1 wild-type allele is located in the vicinity of Xq28 and is approximately $15 \mathrm{~kb}$ in length. This allele, which encodes H/ACA ribonucleoprotein complex subunit 4 protein, plays a role in the stabilization and maintenance of telomerase and H/ACA small nucleolar RNA ribonucleoprotein biogenesis. Mutation of the gene is associated with both Hoyeraal-Hreidarsson syndrome and X-linked dyskeratosis congenita. 